\title{
Determination of Helicobacter pylori virulence-associated genes in duodenal ulcer and gastric biopsies
}

\author{
Yasaman Saeidi ${ }^{1}$, Abazar Pournajaf ${ }^{2}$, Mehrdad Gholami², Meysam Hasannejad-Bibalan², \\ Sajad Yaghoubi ${ }^{3}$, Mahmoud Khodabandeh ${ }^{4}$, Behzad Emadi ${ }^{5}$, Elaheh Ferdosi-Shahandashti ${ }^{6}$, Ramazan Rajabnia ${ }^{7 *}$
}

\begin{abstract}
Background: Helicobacter pylori (H. pylori or Hp) has been strongly associated with the peptic ulcer diseases, chronic gastritis, ulcers, and gastric cancer. Genes associated with pathogenicity have been designated for H. pylori, and some of them appear to be related to more severe clinical consequences of the infection. The present study was conducted to determine $\operatorname{cag} A, \operatorname{vac} A, \operatorname{cag} E$, iceAl, oipA, and iceA2 genes in H. pylori strains isolated from gastroduodenal patients, who referred to Shariati hospital in Tehran, Iran.

Methods: Gastric biopsy specimens were collected during endoscopy from patients, who referred to the Shariati hospital in Tehran, Iran during January and November 2015. After isolation of $H$. pylori from the biopsy culture, genomic DNA was extracted and subsequently used to identify $H$. pylori and virulence genes using specific primers.

Results: The isolation rate of $H$. pylori strains was $65.7 \%$ (169/257). The frequency of cagA, vacA, cagE, iceA1, oipA, and iceA2 was 143 (\% 84.6), 169 (100\%), 131 (77.5\%), 97 (57.3\%), 89 (52.6\%), and 72 (42.6\%), respectively.

Conclusion: In this study, a significant difference was observed between investigated genes and strains isolated from PUD and GC patients $(\mathrm{p}<0.05)$.
\end{abstract}

Keywords: Helicobacter pylori, Iran, Virulence factors, Multiplex PCR, Duodenal ulcers

Copyright $₫$ Iran University of Medical Sciences

Cite this article as: Saeidi Y, Pournajaf A, Gholami M, Hasannejad-Bibalan M, Yaghoubi S, Khodabandeh M, Emadi B, Ferdosi-Shahandashti E, Rajabnia R. Determination of Helicobacter pylori virulence-associated genes in duodenal ulcer and gastric biopsies. Med J Islam Repub Iran. 2017 (17 Dec);31:95. https://doi.org/10.14196/mjiri.31.95

\section{Introduction}

Helicobacter pylori (H. pylori or Hp) is a gram-negative, spiral-shaped, motile, and microaerophilic bacterium that colonizes in the human stomach, however, it may be present in other parts of the body (1). This organism is responsible for a remarkable number of diseases including acute and chronic gastritis, peptic or duodenal ulcer, and gastric cancer (GC) (2). Several virulence factors have been proposed for Hp infections including urease, flagella, adhesions, vacuolating cytotoxin $(\operatorname{Vac} A)$, duodenal ulcer promoting gene $(\operatorname{dup} A)$, outer inflammatory protein $($ Oip $A)$, cytotoxin-associated gene $(\operatorname{Cag} A)$, and $I c e A$ (induced by

Corresponding author: Dr Ramazan Rajabnia, ramazan69@yahoo.com

1. Department of Microbiology, Tonekabon Branch, Islamic Azad University, Tonekabon, Iran.

2. Department of Microbiology, Faculty of Medicine, Iran University of Medical Sciences, Tehran, Iran.

3. Division of Microbiology, Department of Pathobiology, School of Public Health, Tehran University of Medical Sciences, Tehran, Iran.

4. Department of Pediatric Infectious Disease, Faculty of Medicine, Tehran University of Medical Sciences, Tehran, Iran.

5. Department of Microbiology, School of Medicine, Iran University of Medical Sciences, International campus, Tehran, Iran.

6. Department of Medical Biotechnology, Faculty of Medicine, Babol University of Medical Sciences, Babol, Iran.

7. Infectious Diseases and Tropical Medicine Research Center, Babol University of Medical Sciences, Babol, Iran. contact with epithelium) $(3,4)$. The cag pathogenicity island (cag PAI) is a 40-kb DNA insertion element, which encodes CagA. Expression of CagA was found to be intensely related to peptic ulceration $(4,5)$. Thus, the cag PAI is a good criterion for $\mathrm{Hp}$ virulence determination. $\mathrm{Hp}$ strains are commonly divided into $2 \operatorname{Cag} A$-positive and CagA-negative groups, depending on the presence or absence of the final cag PAI gene product (6). The $\operatorname{cag} E$ gene, located on cag PAI, is a Hp virulence determinant associated with more severe illness consequences. Isolates that possess $\operatorname{cag} E$ induce greater chemokine response in vitro

$\uparrow$ What is "already known" in this topic:

Virulence markers of Hp play an important role in gastrointestinal disorders in Iranian patients. Several Hp virulence-associated genes have been reported to be associated with gastroduodenal patients in Iran. In this study, we assessed the relationship between Hp genotype and gastroduodenal pathology.

$\rightarrow$ What this article adds:

Despite a significant difference between investigated genes and strains isolated from PUD and GC patients $(p<0.05)$, further work is required to clarify the roles of $\mathrm{Hp}$ virulence factors in the development of gastroduodenal diseases. 
than those without it $(7,8)$. This may be considered as a potential mechanism for altering disease outcomes after colonization with a Hp that contains $\operatorname{cagE}(9,10)$. Also, cagE could be a risk factor for gastric wounds, may contribute to a good assessment of pathogenic potential of the Hp strains, and may also predict disease development in the gastric mucosa $(11,12)$. Hp-specific vacuolating cytotoxin gene $(v a c A)$ is desirable for rapid, reliable, and accurate detection of Hp-infections (13). Moreover, $v a c A$ is present in all Hp isolates and can promote multiple cellular activities and vacuolation including pore formation and cyt $\mathrm{c}$ release from mitochondria, which can cause cell death and attach to cell surface receptors, starting a proinflammatory reaction. Another virulence factor gene, ice $A$, like $v a c A$, is present in all Hp strains. This gene has 2 ice $A 1$ and ice $A 2$ allelic variants $(14,15)$. IceAl is upregulated during Hp-gastric epithelium contact, and there is an important association between the presence of the iceAl allele and peptic ulcer disease (PUD) (16). Hp iceA1 $1^{+}$genotype enhances mucosal interleukin-8 (IL-8) expression and acute inflammation (17). IceA2 gene has no homology to any known gene and the function is not clear. An epidemiological study found an association between ice $A$ gene and its alleles with gastric and/or duodenal ulcer and GC in different geographic areas (18). Outer inflammatory protein $(O i p A)$ is one of the porin proteins and responsible for pathogen-host interaction. The protein was originally recognized as a proinflammatory response, according to the fact that oip $A$ isogenic mutants decrease the release of IL-8 from gastric epithelial cells (19). Although the prevalence of Hp infection is high, as much as $70 \%$ of developing nations, only few people are affected by serious illnesses caused by this infection (20). This can be attributed to the participation of particular elements that contribute to the pathogenicity of this microorganism. Thus, the present study aimed at investigating the $\operatorname{cag} A, \operatorname{cag} E, \operatorname{vac} A$, oip $A$, ice $A 1$, and ice $A 2$ genes in Hp strains isolated from gastroduodenal biopsies in patients admitted to Shariati hospital in Tehran, Iran.

\section{Methods}

In this cross-sectional study, which was conducted during January and November 2015, a total of 257 nonduplicative and nonreiterative biopsy samples were collected by gastroenterologists from each untreated patient, who underwent upper gastroduodenal endoscopy in Shariati hospital in Tehran, Iran. Shariati hospital is one the most equipped teaching therapeutic centers affiliated to Tehran University of Medical sciences (TUMS), with more than 857 beds. In total, 257 patients (132 males and 125 females) aged 18 to 91 years, with an average age of 53.1 years and clinical manifestations of abdominal pain or burning, nausea, vomiting, frequent burping, bloating, and weight loss, were enrolled in the study. Those who received Hp eradication therapy protocol or anti-Hp therapy, bismuth-containing regimens, proton pump inhibitors (PPIs), nonsteroidal antiinflammatory drugs (NSAIDs) or $\mathrm{H}_{2}$-receptor antagonists within 4 weeks prior to the project were excluded. Informed consent was obtained from all contributors. Two gastric mucosal biopsy samples (1 antrum and 1 corpus biopsy specimens) were obtained from each patient. Samples were used for culture and molecular examination. All samples were immediately placed in Stuart's medium and transferred to a microbiology laboratory within 2 hours and kept at $4{ }^{\circ} \mathrm{C}$. After homogenization with an electric tissue homogenizer (Ultraturrax, Iena, Germany), the biopsy specimens were streaked in the Campylobacter agar plates (Merck Co., Germany) supplemented with 10\% defibrinated sheep blood and a set of specified antibiotics comprising $5 \mathrm{mg} / \mathrm{L}$ trimethoprim, $10 \mathrm{mg} / \mathrm{L}$ vancomycin, $5 \mathrm{mg} / \mathrm{L}$ cefsulodin, and $5 \mathrm{mg} / \mathrm{L}$ amphotericin B. Each plate was incubated at $37^{\circ} \mathrm{C}$ for 5 to 7 days under microaerophilic conditions $\left(85 \% \mathrm{~N}_{2}, 10 \% \mathrm{CO}_{2}\right.$ and $\left.5 \% \mathrm{O}_{2}\right)$. All suspected grown colonies were identified as $\mathrm{Hp}$ based on conventional microbiological and biochemical tests. All isolates were kept in the Brain Heart Infusion Broth (Merck Co., Germany) with $20 \%$ glycerol and stored at $-70{ }^{\circ} \mathrm{C}$ for further DNA extraction. Then, genomic DNA was extracted using the ExiProgen ${ }^{\mathrm{TM}}$ Bacteria Genomic DNA Kit (Bioneer Co., Korea) in accordance with the manufacturer's instructions. The quality and quantity of the extracted DNA were evaluated using a NanoDrop spectrophotometer (ND1000; Thermo Scientific; Wilmington, DE, USA). The $v a c A$ gene was detected to confirm $\mathrm{Hp}$ in gastric biopsies. Multiplex PCR was performed for amplification of $v a c A$, $\operatorname{cag} A, \operatorname{cag} E$, iceA1, iceA2, and oip $A$ genes in a volume of $0.6 \mu \mathrm{L}(0.5 \mu \mathrm{g})$ of template genomic DNA and then added to a final volume of $25 \mu \mathrm{L}$ PCR reaction mixture containing $2.0 \mu \mathrm{L}$ of $10 \times$ PCR buffer, $0.9 \mu \mathrm{L} \mathrm{MgCl}_{2}(50 \mathrm{mM}), 0.5 \mu \mathrm{L}$ dNTPs $(10 \mathrm{mM}), 1.2 \mu \mathrm{L}$ of each primer, $0.7 \mu \mathrm{L}$ of Taq DNA polymerase ( $5 \mathrm{U} / \mu \mathrm{L})$ (Amplicon Co., Denmark), and

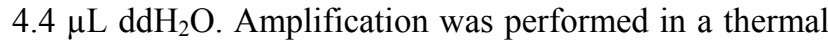
gradient cycler (Eppendorf Co., Germany). The cycling conditions were as follow: initial denaturation at $95^{\circ} \mathrm{C}$ for 4 minutes, 31 cycles with denaturation at $95^{\circ} \mathrm{C}$ for $44 \mathrm{sec}-$ onds, annealing at $51^{\circ} \mathrm{C}$ for 45 seconds, extension at $72^{\circ} \mathrm{C}$

Table 1. Oligonucleotide primer sequences used in the study

\begin{tabular}{|c|c|c|c|}
\hline Target Gene & Primer sequence $\left(5^{\prime} \rightarrow 3^{\prime}\right)$ & Amplicon size (bp) & Ref \\
\hline \multirow[t]{2}{*}{$\overline{c a g E}$} & F:5'- TTGAAAACTTCAAGGATAGGATAGAGC-3' & 500 & 21 \\
\hline & R:5'- GCCTAGCGTAATATCACCATTACCC-3' & & \\
\hline \multirow[t]{2}{*}{$\operatorname{cag} A$} & F: 5'- AATACACCAACGCCTCCAAG-3' & 298 & 22 \\
\hline & R: 5'- TTGTTGGCGCTTGCTCTC-3' & & \\
\hline \multirow[t]{2}{*}{ iceA1 } & F: 5'- GTGTTTTTAACCAAAGTATC-3' & 247 & 23 \\
\hline & R: 5'- CTATAGCCASTCTCTTTGCA-3' & & \\
\hline \multirow[t]{2}{*}{ iceA2 } & F: 5'- GTTGTCGTTGTTTTAATGAA-3' & 120 & 24 \\
\hline & R: 5'- GTCTTAAACCCCACGATTAAA-3' & & \\
\hline \multirow[t]{2}{*}{$\operatorname{Vac} A$} & F: 5'- GCCGATATGCAAATGAGCCGC-3' & 678 & 24 \\
\hline & R: 5'- CAATCGTGTGGGTTCTGGAGC-3' & & \\
\hline \multirow[t]{2}{*}{ oipA } & F: 5'- GTTTTTGATGCATGGGATTT-3' & 401 & 25 \\
\hline & R: 5'- GTGCATCTCTTATGGCTTT -3' & & \\
\hline
\end{tabular}


for 62 seconds, and final extension at $72^{\circ} \mathrm{C}$ for 5 minutes. The amplified products were visualized by electrophoresis in $1.5 \%$ agarose gels stained with Gel RedTM. Table 1 summarizes the primer sequences and the expected size of products. Positive and negative controls were evaluated with test samples on each run.

\section{Ethics statement}

The bacterial isolates analyzed in this study were collected by gastroenterologists from each untreated patient, who underwent upper gastroduodenal endoscopy in Shariati hospital in Tehran, Iran. Furthermore, all patient identifiers had been previously removed and data anonymity was assured (No.1395.9221133207).

\section{Results}

The presence of Hp infection in the participants was determined by microbiological culture examination and vacA gene polymerase chain reaction (PCR). Our patients were categorized into the following 3 groups based on the clinical data: 123 (72.78\%) peptic ulcer diseases (PUD; duodenal and gastric ulcers), 41 (24.2\%) non-ulcer dyspepsia (NUD; gastritis and duodenitis), and 5 (2.9\%) GC (Table 2). Of 257 biopsy samples, 169 (65.7\%) Hp strains were obtained. The distribution analysis of the Hp isolates revealed that most isolates $(\mathrm{N} ; 87,51.4 \%)$ were recovered from the gastric ulcer and the lowest isolates $(\mathrm{N} ; 5,2.9 \%)$ from GC. The highest and lowest prevalence of virulenceassociated genes were detected in patients with gastric ulcer and $\mathrm{GC}$, respectively. The highest frequency $(\mathrm{N} ; 87$, $51.4 \%$ ) of virulence genes in the biopsy specimens obtained from gastric ulcer was $84.6 \%$ ( cagA), 77.5\% (cagE), 57.3\% (iceA1), 42.6\% (iceA2), and 52.6\% (oipA), respectively (Table 2). The highest and lowest genotypes were cagE/oipA $(\mathrm{N} ; 42,24.8 \%)$ and cagA/oipA/cagE/ iceA1 (N; $15,8.8 \%$ ) (Table 3 ).

\section{Discussion}

Using culture-based method and PCR-amplified vacA genes, we found that of the 257 biopsy samples, 169 were positive for Hp. Moreover, Hp strains were detected in patients with gastric ulcer $(\mathrm{N} ; 87 ; 51.4 \%)$ significantly more frequently than in those with other gastroduodenal disorders. The $\operatorname{cag} A$ results $(84.6 \%)$ in our study are similar to those obtained in Mexican (86\%) and Japanese studies $(90 \%)(26,27)$. These data are in contrast with those of other studies in other countries including Pakistan (56\%), Iraq (71\%), India, and Bangladesh (70\%) (28). The cag PAI encoded effector proteins for the type IV secretion system (T4SS of TFSS) mediate construction of CagA peptidoglycan and probably other bacterial factors into host cells cytoplasm, which are the chief cause of inflammation. A previous study found that $c a g \mathrm{~A} / E / M / T$ of $c a g P A I$ was used as a valuable marker for the risk of PUD. In our study, the prevalence of the $\operatorname{cag} A$ gene in strains isolated from patients with gastric ulcer was $85 \%$ (74 of 87). The $c a g E$ gene is located on the cag $P A I$ and involves in the creation of the bacterial transport system and IL- 8 production in gastric epithelial cells. In our study, the $\operatorname{cag} E$ gene was present in 131 of the 169 strains $(77.5 \%)$. The prevalence of $c a g E$ was found in $70 \%, 81.6 \%$, and $39 \%$ of Hp isolates in Malaysia, India, and China, respectively (29). In Tiwari et al. study, $\operatorname{cag} E$ was found in a larger proportion of the ulcer group (92.5\%) compared with the NUD group (77.5\%) (30). In studies of Podzorski et al. (31) and Li et al. (32), the frequency of $\operatorname{cag} E$ gene was $62 \%$ and $99 \%$, respectively. The ice $A$ gene has 2 allelic forms: iceA1 and iceA2. The iceA1 has been described to be the prevalent gene in many studies, while ice $A 2$ is a prevalent allele in others (33). The iceA1 gene was most frequent in this study $(57.9 \%)$. A Brazilian study reported a rate of $90.1 \%$ for the ice $A 2$ (34). In contrast, A Mexican study reported a rate of $9 \%$ for the ice $A 2$ allele (35). In East Asia, the iceAl genotype has been reported to be predominant $(76 \%)$, while icaA2 is predominant in Portugal and Colombia (36). These differences in ice $A$ gene rates in several countries are strongly suggestive of its geographical distribution. Our study results revealed that all $\mathrm{Hp}$ strains $(100 \%)$ were positive for $v a c A$ gene. According to other studies in Iran, the vacA s1 and s1m1 genotypes are also the dominant genotypes among Iranian patients with a high rate $(90 \%)(37)$. However, the collective

\begin{tabular}{|c|c|c|c|c|c|c|}
\hline \multirow{2}{*}{$\begin{array}{l}\text { Gastroduodenal } \\
\text { pathology }\end{array}$} & \multicolumn{2}{|c|}{ No. (\%) of positive for $H$. pylori } & \multicolumn{3}{|c|}{ Distribution of virulence factors $(\%)$} & \\
\hline & & $\operatorname{cag} A$ & $\operatorname{cag} E$ & iceA1 & \multirow{2}{*}{$\begin{array}{c}i c e A 2 \\
46(52.8)\end{array}$} & \\
\hline Gastric ulcer & $87(51.4)$ & $74(85)$ & $75(86.2)$ & $61(70.1)$ & & $\begin{array}{c}\text { oipA } \\
52(59.7)\end{array}$ \\
\hline Duodenal ulcer & $36(21.3)$ & $28(77.7)$ & & $17(47.2)$ & $16(44.4)$ & $20(55.5)$ \\
\hline Gastric cancer & $5(2.9)$ & $5(100)$ & $2(40)$ & \multirow{2}{*}{$\begin{array}{c}3(60) \\
13(43.3)\end{array}$} & $1(20)$ & $1(20)$ \\
\hline Gastritis & $30(17.7)$ & $29(96.6)$ & $25(83.3)$ & & $6(20)$ & $15(50)$ \\
\hline Duodenitis & $11(6.7)$ & $7(63.6)$ & $6(54.5)$ & $3(27.2)$ & $3(27.2)$ & $1(9)$ \\
\hline Total & $169(100)$ & $143(84.6)$ & $131(77.5)$ & $97(57.3)$ & $72(42.6)$ & $89(52.6)$ \\
\hline \multirow[b]{2}{*}{ Genotype } & \multicolumn{6}{|c|}{ No. of patients with gastroduodenal pathology (\%) } \\
\hline & Gastric ulcer & Duodenal ulcer & $\begin{array}{c}\text { Gastric cañ- } \\
\text { cer }\end{array}$ & Gastritis & Duodenitis & Total \\
\hline $\operatorname{cag} A^{+} /$oip $A^{+}$ & $20(22.9)$ & $6(16.6)$ & $1(20)$ & $8(26.6)$ & $2(18.1)$ & $37(21.8)$ \\
\hline $\operatorname{cag} E^{+} / \operatorname{oip} A^{+}$ & $21(24.1)$ & $7(19.5)$ & $1(20)$ & $10(33.6)$ & $3(27.4)$ & $42(24.8)$ \\
\hline $\operatorname{cag} A^{+} /$oipA $^{+} /$iceAl $^{+}$ & $10(11.5)$ & $6(16.7)$ & $2(40)$ & $2(6.6)$ & $2(18.1)$ & $22(13.2)$ \\
\hline $\operatorname{cag} A^{+} /$oip $^{+} / \operatorname{cagE}^{+} /$iceAl $^{+}$ & $6(6.9)$ & $5(13.8)$ & $1(20)$ & $2(6.6)$ & 1(9) & $15(8.8)$ \\
\hline Others & $30(34.6)$ & $12(33.4)$ & 0 & $8(26.6)$ & $3(27.4)$ & $53(31.4)$ \\
\hline Total & $87(100)$ & $36(100)$ & $5(100)$ & $30(100)$ & $11(100)$ & $169(100)$ \\
\hline
\end{tabular}


assessment of the vacA genotype determined most of $\mathrm{s} 1 \mathrm{~m} 2$ genotypes in patients with PUD, which was remarkably correlated with the disease $(p<0.05)$ in other works $(38)$. These variations may contribute to the varying prevalence of gastric diseases in these areas. We found that $52.6 \%$ of isolated strains contain oipA gene. These data are in contrast with those of Yamaoka et al. (39) and Kudo et al., who identified the oip $A$ gene from $45.9 \%$ and $30 \%$ of studied Hp isolates, respectively (40). In most studies, the oip $A$ gene was present in most strains. In contrast, there were many oip $A$-negative cases in our study.

\section{Conclusion}

These results revealed that the high number of $\mathrm{Hp}$ strains may be considered as highly virulent, as they possessed 3, 4 , or even 5 of the virulence markers analyzed. In this study, a significant difference was observed between investigated genes and strains isolated from PUD and GC patients $(p<0.05)$. However, no significant difference was found in the NUD patients $(\mathrm{p}=0.08)$. Although there was variation in the prevalence of the $\operatorname{cag} A, \operatorname{cag} E$, iceA1, ice $A 2$, and vacA in HP strains isolated from patients in this study, this distribution was not statistically significant in our studied population.

\section{Acknowledgment}

The authors acknowledge Dr. Gholamreza Irajian for his opportune advises and contribution to this paper. We also greatly appreciate the assistance of the staff at the Gastroenterological Unit in Shariati hospital in Tehran, Iran, for their great support during this investigation.

\section{Conflict of Interests}

The authors declare that they have no competing interests.

\section{References}

1. Makola D, Peura DA, Crowe SE. Helicobacter pylori infection and related gastrointestinal diseases. J Clin Gastroenterol. 2007;41(6):54858.

2. Vala MH, Eyvazi S, Goudarzi H, Sarie HR, Gholami M. Evaluation of Clarithromycin Resistance Among Iranian Helicobacter pylori Isolates by E-Test and Real-Time Polymerase Chain Reaction Methods. Jundishapur J Microbiol. 2016;9(5).

3. Matsumoto Y, Marusawa H, Kinoshita K, Endo Y, Kou T, Morisawa $\mathrm{T}$, et al. Helicobacter pylori infection triggers aberrant expression of activation-induced cytidine deaminase in gastric epithelium. Nat Med. 2007;13(4):470-6.

4. Atherton JC. H. pylori virulence factors. Br Med Bull. 1998; 54(1):10520 .

5. Kusters JG, van Vliet AH, Kuipers EJ. Pathogenesis of Helicobacter pylori infection. Clin Microbiol Rev. 2006;19(3):449-90.

6. Viala J, Chaput C, Boneca IG, Cardona A, Girardin SE, Moran AP, et al. Nod1 responds to peptidoglycan delivered by the Helicobacter pylori cag pathogenicity island. Nat Immunol 2004;5(11):1166-74.

7. Kiani AH, Asadbeik E, Bibalan MH, Sedighi M, Eshaghi M, Gholami $\mathrm{M}$, et al. Serological diagnosis of Helicobacter pylori infection in patients with a polycystic ovary syndrome. Arch Clin Infect Dis. 2015;10(2).

8. Shariq M, Kumar N, Kumari R, Kumar A, Subbarao N, Mukhopadhyay G. Biochemical Analysis of CagE: A VirB4 Homologue of Helicobacter pylori Cag-T4SS. PloS one. 2015;10(11):e0142606.

9. Mattar R, Marques SB, do Socorro Monteiro M, dos Santos AF, Iriya $\mathrm{K}$, Carrilho FJ. Helicobacter pylori cag pathogenicity island genes: clinical relevance for peptic ulcer disease development in Brazil. J Med
Microbiol. 2007;56(1):9-14.

10. Salama NR, Hartung ML, Müller A. Life in the human stomach: persistence strategies of the bacterial pathogen Helicobacter pylori. Nat Rev Microbiol. 2013;11(6):385-99.

11. Backert S, Selbach M. Role of type IV secretion in Helicobacter pylori pathogenesis. Cell mic. 2008;10(8):1573-81.

12. Yamaoka Y. Mechanisms of disease: Helicobacter pylori virulence factors. Nat Rev Gastroenterol Hepatol. 2010;7(11):629-41.

13. Wu C-C, Chou P-Y, Hu C-T, Liu Z-C, Lin C-Y, Tseng Y-H, et al. Clinical relevance of the vacA, iceA, cagA, and flaA genes of Helicobacter pylori strains isolated in Eastern Taiwan $\mathrm{J}$ Clin Microbiol. 2005;43(6):2913-5.

14. Feliciano O, Gutierrez O, Valdés L, Fragoso T, Calderin AM, Valdes AE, et al. Prevalence of Helicobacter pylori vacA, cagA, and iceA genotypes in Cuban patients with upper gastrointestinal diseases. Biomed Res Int. 2015;2015:753710.

15. Kauser F, Khan AA, Hussain MA, Carroll IM, Ahmad N, Tiwari S, et al. The cag pathogenicity island of Helicobacter pylori is disrupted in the majority of patient isolates from different human populations. J Clin Microbiol. 2004;42(11):5302-8.

16. Podzorski RP, Podzorski DS, Wuerth A, Tolia V. Analysis of the vacA, cagA, cagE, iceA, and babA2 genes in Helicobacter pylori from sixty-one pediatric patients from the Midwestern United States. Diagn Microbiol Infect Dis. 2003;46(2):83-8.

17. Ladeira MS, Rodrigues MA, Salvadori DM, Neto PP, Achilles P, Lerco MM, et al. Relationships between cagA, vacA, and iceA genotypes of Helicobacter pylori and DNA damage in the gastric mucosa. Environ Mol Mutagen. 2004;44(2):91-8.

18. Xu Q, Morgan R, Roberts R, Xu S, Van Doorn L, Donahue J, et al. Functional analysis of iceA1, a CATG-recognizing restriction endonuclease gene in Helicobacter pylori. Nucleic Acids Res. 2002;30(17):3839-47.

19. Chen J, Lin L, Li N, She F. Enhancement of Helicobacter pylori outer inflammatory protein DNA vaccine efficacy by co-delivery of interleukin-2 and B subunit heat-labile toxin gene encoded plasmids. Microbiol Immunol. 2012;56(2):85-92.

20. Bruce MG, Maaroos HI. Epidemiology of Helicobacter pylori infection. Helicobacter. 2008;13(s1):1-6.

21. Tomasini ML, Zanussi S, Sozzi M, Tedeschi R, Basaglia G, De Paoli $P$. Heterogeneity of cag genotypes in Helicobacter pylori isolates from human biopsy specimens. J Clin Microbiol. 2003;41(3):976-80.

22. Zheng P, Hua J, Yeoh K, Ho B. Association of peptic ulcer with increased expression of Lewis antigens but not cagA, ice A, andvacA in Helicobacter pylori isolates in an Asian population. Gut. 2000;47(1):18-22.

23. van Doorn LJ, Figueiredo C, Sanna R, Plaisier A, Schneeberger P, de Boer W, et al. Clinical relevance of the cagA, vacA, and iceA status of Helicobacter pylori. Gastroenterology. 1998;115(1):58-66.

24. Tan HJ, Rizal A, Rosmadi M, Goh L. Distribution of Helicobacter pylori cagA, cagE and vacA in different ethnic groups in Kuala Lumpur, Malaysia. J Gastroenterol Hepatol. 2005;20(4):589-94.

25. Chattopadhyay S, Patra R, Ramamurthy T, Chowdhury A, Santra A, Dhali G, et al. Multiplex PCR assay for rapid detection and genotyping of Helicobacter pylori directly from biopsy specimens. J Clin Microbiol. 2004;42(6):2821-4.

26. González-Vázquez R, Herrera-González S, Cordova-Espinoza MG, Zúñiga G, Giono-Cerezo S, Hernández-Hernández JM, et al. Helicobacter pylori: detection of iceA1 and iceA2 genes in the same strain in Mexican isolates. Arch Med Res. 2012;43(5):339-46.

27. Maeda S, Ogura K, Yoshida H, Kanai F, Ikenoue T, Kato N, et al. Major virulence factors, $\mathrm{VacA}$ and CagA, are commonly positive inHelicobacter pylori isolates in Japan. Gut. 1998;42(3):338-43.

28. Essawi T, Hammoudeh W, Sabri I, Sweidan W, Farraj MA. Determination of Helicobacter pylori virulence genes in gastric biopsies by PCR. Int Sch Res Notices. 2013. Article ID 606258, 4 pages.

29. Dabiri H, Maleknejad P, Yamaoka Y, Feizabadi MM, Jafari F, Rezadehbashi M, et al. Distribution of Helicobacter pylori cagA, cagE, oipA and vacA in different major ethnic groups in Tehran, Iran. J Gastroenterol Hepatol. 2009;24(8):1380-6.

30. Tiwari SK, Khan AA, Ahmed KS, ALI S, Ahmed I, Habeeb A, et al. Polymerase chain reaction based analysis of the cytotoxin associated gene pathogenicity island of Helicobacter pylori from saliva: an approach for rapid molecular genotyping in relation to disease status. $\mathrm{J}$ Gastroenterol Hepatol. 2005; 20(10):1560-6.

31. Podzorski RP, Podzorski DS, Wuerth A, Tolia V. Analysis of the 
vacA, cagA, cagE, iceA, and babA2 genes in Helicobacter pylori from sixty-one pediatric patients from the Midwestern United States. Diagn Microbiol Infect Dis. 2003;46(2):83-8.

32. Li X, Liu W, Xu W, Shi Y, Xiao S. Clinical implications and prevalence of cagA, cagE and cagT genes in the pathogenicity island of Helicobacter pylori strains isolated from Shanghai patients. J Dig Dis 2001; 2(3):133-6.

33. Kim SY, Woo CW, Lee YM, Son BR, Kim JW, Chae HB, et al. Genotyping CagA, VacA subtype, IceA1 and BabA of Helicobacter pylori isolates from Korean patients, and their association with gastroduodenal diseases. J Korean Med Sci. 2001;16(5):579.

34. Ashour AAR, Collares GB, Mendes EN, de Gusmão VrR, de Magalhães Queiroz DM, Magalhães PP, et al. iceA genotypes of Helicobacter pylori strains isolated from Brazilian children and adults. J Clin Microbiol. 2001;39(5):1746-50.

35. González-Vázquez R, Herrera-González S, Cordova-Espinoza MG, Zúñiga G, Giono-Cerezo S, Hernández-Hernández JM, et al. Helicobacter pylori: detection of iceA1 and iceA2 genes in the same strain in Mexican isolates. Arch Med Res. 2012:43(5):339-46.

36. Wu CC, Chou PY, Hu CT, Liu ZC, Lin CY, Tseng YH, et al. Clinical relevance of the vacA, iceA, cagA, and flaA genes of Helicobacter pylori strains isolated in Eastern Taiwan. J Clin Microbiol. 2005;43(6):2913-5.

37. Pajavand H, Alvandi A, Mohajeri P, Bakhtyari S, Bashiri H, Kalali B, et al. High Frequency of vacA s1m2 Genotypes Among Helicobacter pylori Isolates from Patients with Gastroduodenal Disorders in Kermanshah, Iran. Jundishapur J Microbiol. 2015; 22; 8(11):e25425.

38. Hosseini E, Poursina F, Van de Wiele T, Safaei HG, Adibi P. Helicobacter pylori in Iran: A systematic review on the association of genotypes and gastroduodenal diseases. J Res Med Sci. 2012; 17(3):280-92.

39. Yamaoka Y, Ojo O, Fujimoto S, Odenbreit S, Haas R, Gutierrez O, et al. Helicobacter pylori outer membrane proteins and gastroduodenal disease. Gut. 2006;55(6):775-81.

40. Kudo T, Nurgalieva ZZ, Conner ME, Crawford S, Odenbreit S, Haas $\mathrm{R}$, et al. Correlation between Helicobacter pylori OipA protein expression and oipA gene switch status. J Clin Microbiol. 2004;42(5):227981 . 